\title{
JOURNAL.RU
}

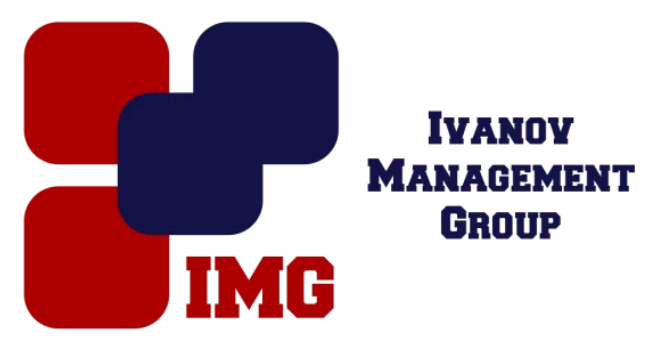

Байбара В.С. СГТУ им. Ю.А. Гагарина

Саратов, Россия

doi: 10.18411/lj-31-10-2016-2-01

idsp 000001:lj-31-10-2016-2-01

\section{Разработка композиционного огне- и теплозащитного материала на основе фторсодержащих полимеров для жизнеобеспечения биологических объектов в экстремальных условиях}

Научный руководитель: Пичхидзе С.Я.

В настоящее время актуален вопрос о разработке материалов предназначенных для жизнеобеспечения человека в экстремальных условиях. Поставлена задача о предании тканям тепло и огнезащитных свойств. В патентах [1...3] в основном придание негорючести тканям, обладающим высокой стойкостью к истиранию, проводится за счет нанесения на поверхность пленочного покрытия на основе каучука СКТН, также используется принцип объемной пропитки материала огнезащитным составом из хлорвинилового парафина, сополимера этилена и винилацетата, трехокиси сурьмы. Недостатки этих разработок - вулканизация при комнатной температуре, то есть нестабильность; трехокись сурьмы ограничивает гигиенические показатели данных материалов. На основе проведенного патентного поиска [1...3] установлено, что основными способами придания огнезащитных свойств текстильным материалам являются: обработка тканей растворами антипиренов; нанесение негорючих покрытий на поверхность материала.

Цель работы: разработка способа огнестойкой обработки ткани, также создание композиционного материла для пропитки тканных и нетканых поверхностей. 
В качестве объекта исследования были выбраны материалы: аминосилан АГМ-9 по ТУ 6-02-724-77 и фторопластовая дисперсия Ф-4Д по ТУ 6-05-1246-81 и нетканый материал на основе полиакрилонитрила и поливинилиденфторида [4]. Пропитку наносили методом окунания материала в состав. Сушку образцов проводили при температуре 20ОС. Негорючесть материалов оценивали посредством воздействия высоких температур в течение 12с (горелка) [5, 6], см. рис. 1 и табл. 1.

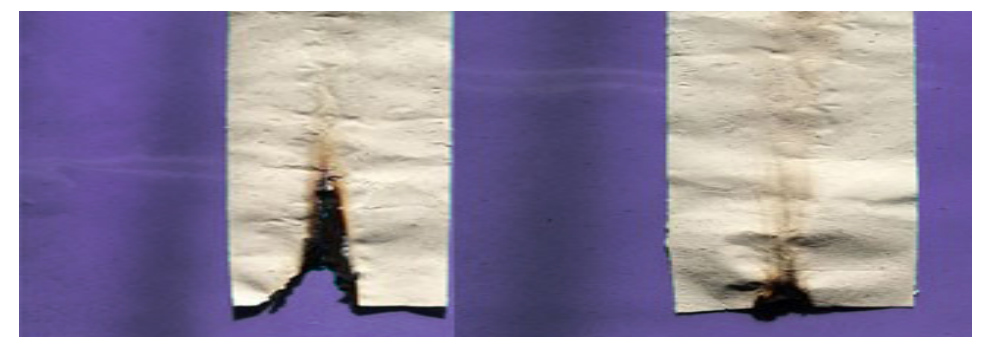

a)

б)

Рис.1. Внешний вид образияов после воздействия пламени с пропиткой АГМ-9 (а) и с пропиткой Ф-4Д (б) Данные по параметрам огнезащитных образиов

\begin{tabular}{|c|c|c|c|c|c|c|c|c|}
\hline № & $\begin{array}{c}\text { Пропит- } \\
\text { ка }\end{array}$ & $\begin{array}{c}\text { Концентра- } \\
\text { ция раствора, } \\
\text { моль/л }\end{array}$ & $\begin{array}{c}\text { Изме- } \\
\text { нение } \\
\text { массы } \\
\text { образ- } \\
\text { ца, г }\end{array}$ & $\begin{array}{c}\text { Измене- } \\
\text { ние массы } \\
\text { образца, } \\
\text { \% }\end{array}$ & $\begin{array}{c}\text { Поверх- } \\
\text { ностная } \\
\text { плот- } \\
\text { ность, г/м² }\end{array}$ & $\begin{array}{c}\text { Высо- } \\
\text { та } \\
\text { выгора } \\
\text { ния, } \\
\text { мм } \\
\end{array}$ & $\begin{array}{c}\text { Пло- } \\
\text { щадь } \\
\text { выго- } \\
\text { рания, } \\
\text { мм² }^{2}\end{array}$ & $\begin{array}{c}\text { Приме- } \\
\text { чание }\end{array}$ \\
\hline 1 & отсутств. & - & 0 & 0 & 20 & 120 & 930 & \multirow{5}{*}{$\begin{array}{c}\text { Мате- } \\
\text { риал не } \\
\text { хруп-кий }\end{array}$} \\
\hline 2 & АГМ-9 & 0,05 & 0.04 & 6,95 & 30 & 70 & 525 & \\
\hline 3 & & 0,03 & 0.02 & 3,13 & 27 & 90 & 675 & \\
\hline 4 & Ф-4Д & по ТУ & 1,34 & 59 & 88 & 12 & 90 & \\
\hline 5 & & по ТУ & 0.70 & 31 & 42 & 20 & 170 & \\
\hline
\end{tabular}

Анализ экспериментальных результатов показывает, что высота выгорания образца при использовании аминосилана АГМ-9 снизилась в 1,4 ...1,8 раза, при применении дисперсии Ф-4Д в $5 \ldots 9$ раз.

Выводы: установлено, что пропитка нетканого материала дисперсией Ф4Д имеет высокую эффективность. 


\section{Литература}

1. Патент РФ № 2203993 на изобретение / Журко А.В., Хелевин Р.Н., Никитин Ю.А. // Огнестойкий текстильный материал. -2003.

2. Патент США №4032517/Оскар А. Пикетт, младший, Джон У. Стоддард // Фосфорсодержащие сополиамиды и их волокна. - 1977.

3. Патент РФ на изобретение №2265683/ Журко А.В., Хелевин Р.Н., Уткин Г.В. // Композиция для получения огнестойких текстильных материалов.22.12.2003.

4. Байбара В.С., Пичхидзе С.Я. Разработка огнезащитного и пламягасящего материала одежды. Балаково, БИТИ НИЯУ МИФИ, Молодой ученый, 24.1 (104.1), 2015.-c.58-60.

5. ГОСТ 11209-85. Ткани хлопчатобумажные и смешанные защитные для спецодежды. Технические условия,

6. ГОСТ 15898-70. Ткани льняные и полульняные. Метод определения огнестойкости. 